\title{
Breaking The Silence: Articulating The Memories Of The Tanjung Priok Victims ${ }^{1}$
}

\author{
Wahyudi Akmaliah ${ }^{2}$ \\ Research Center for Society and Culture \\ Indonesian Institute of Sciences
}

\begin{abstract}
For the victims of atrocities, the past is not the past: it remains a trauma. The more they try to forget, the more entrenched their memories become. Hence, memory is a means for sustaining their quest for justice-a way victims and their advocates can keep faith in their pursuit of truth, accountability and legal restitution. Unlike the situation during the Suharto presidency when the Indonesian people were silenced, this paper is now able to examine the memories, now articulated, of the people affected by the Tanjung Priok tragedy, which have appeared since Suharto's fall. This gives momentum to a new phase of political development in which Indonesians, particularly the victims of violence, may break their silence to pursue justice. The following questions need to be asked: what are the circumstances that have encouraged the victims to articulate their memories in the 17 years since Suharto's departure? In what way have they kept their memories fresh? This paper argues that the main reason they articulate their memory is because of the traumas that always haunted them during the Suharto presidency. The trauma and injustices experienced; the torture, gaol, and the stigma attached to them by the Suharto regime's propaganda, all ensured that the general Indonesian social memory of the events at Tanjung Priok was false and distorted. But those sites of memory, the rites, monuments, and memoirs served to strengthen the articulation of those memories to enable some redress after Suharto regime had ended.
\end{abstract}

Keywords: Victims and their families, Tanjung Priok, Post-Suharto regime, Sites of memory

\section{INTRODUCTION}

For victims of atrocities, the past is not past: the trauma remains. The more they try to forget the events, the more the past intrudes. This shows that there has been no closure. Memory is a means for sustaining the quest for justice - a way by which victims and their advocates can keep faith with their pursuit of truth, accountability and legal redress. For their part, the perpetrators similarly focus on the past; they use memory, not as an instrument of legal accountability, but as tool for justification; as a way to rationalise past individual and collective actions, even when those actions resulted in great human suffering (Amstutz, 2005: ix). Indeed, the perpetrators had been called heroes, warriors of the

1 This paper has been presented at the 3rd Singapore Graduate Forum on Southeast Asia Studies, 28-29 July 2008, Asia Research Institute, National University of Singapore. I thank Professor Dr Roxana Waterson for her useful comments and corrections and Dr. Budiawan for his mentorship during my study in the post graduate of Religious and Cultural Studies, Sanata Dharma University, Yogyakarta .

2 Researcher at the Research Center for Society and Culture, Indonesian Institute of Sciences (PMB-LIPI). E-mail address: wahyudiakmaliah@gmail.com. 
nation state. For the Tanjung Priok victims, keeping memories strong by articulating their experiences is to keep alive their hopes for eventual justice.

In 1984, many Muslims in the Tanjung Priok community attended an Islamic gathering (Pengajian Akbar) in Sindang Street, Tanjung Priok, North Jakarta, to request the police authorities to release fellow Muslims from Kampung Koja, Tanjung Priok, who had been arrested on 10 September 1984. Their arrest was the result of a conflict with Sertu Hermanu, a police officer, at a small mosque, Musholla Assa'adah. Sertu Hermanu had entered this small mosque without taking his shoes off and he had removed pamphlets from the walls using dirty water from a drain. This caused great anger in the Tanjung Priok Muslim community. The Tanjung Priok Muslims and many other Indonesian Muslims had previously controlled their anger at Indonesian government policies that had made them feel marginalised. Instances were the ban on senior-high-school, female students covering their heads, the promotion of keluarga berencana (family planning), and the plan to make the Pancasila ideology the prime ideology or belief for all Indonesian people.

On the night of 12 September 1984, while the Muslims of Tanjung Priok were attending a rally to ask the military officials in Komando Distrik Militer (Kodim) Office 0502 to release four fellow Muslims who had been taken into custody, soldiers opened fire on the demonstrators. More than three hundred people were killed, others were held without trial for years, including some people who knew nothing of what was happening in Tanjung Priok but had just been passing by.

During Suharto's presidency, no investigation was ever allowed of what happened on 12 September 1984. Therefore, neither survivors nor the families of those who had been killed or been arrested were able to make any inquiries about what had happened to their family members, nor to bring any charges against the government for what had happened. Indeed, they themselves were stigmatised as subversives who were undermining the stability of the state. The victims and their families were thus forced to live in the shadow of a stigma, and they had to keep to themselves their memories of the traumas resulting from the massacre.

This paper examines the articulation of the memories of the Tanjung Priok tragedy that appeared in post-Suharto times. As is well known, the fall of the Suharto regime in May 1998 opened a new process of democratisation in Indonesia. It has also given momentum to a new phase of political development. One result of this is the freedom to ask questions about the government's responsibility for human rights abuses during the Suharto regime. The demand for the truth is coming from the victims of these injustices. One such group comprises the survivors of the Tanjung Priok massacre, who are now trying to articulate their memories of the events, which could not be done publicly under Suharto's Orde Baru (New Order) government. Their memories of those traumatic events remained to haunt them. The more such victims try to forget what happened, the less able they are to do so. Truth seeking, then, together with efforts to bring the perpetrators to justice, is necessary for the victims to be able finally to deal with the past. To enable an explanation, this paper poses several questions: what are the reasons for victims wanting to articulate their memories even though the New Order's authority collapsed 17 years ago? In what way have they ensured that their memories of events have not faded?

\section{THE VOICES REAPPEAR OF THOSE WHO HAD REMAINED SILENT}

Several months after Reformasi got underway (that is, the government administration that followed the New Order), national newspapers carried a story that suggested that survivors and families of the victims of the Tanjung Priok atrocities on 12 September 1984 should get in touch with Mrs Dewi Wardah in the district of Kebon Bawang, Tanjung Priok, in North Jakarta'. ${ }^{3}$ After reading this article, Mrs Yetty, a family member of one of the victims, went to meet Mrs Dewi Wardah. By so

3 Information from an interview on 8 November 2006 with Mrs Yetty, one of the victims' family. 
doing, Mrs Yetty was able achieve what she had dreamed of and had waited 14 years for, that is, to get and to give information about her father who had been a victim in Tanjung Priok in $1984 .^{4}$ She was able to release her stories about the traumas stemming from the loss of her father.

It was a similar situation for Mr Jaja A Raharja, another of the victims of Tanjung Priok. At the time, Mr Jaja, by unlucky chance, was walking through the area of the tragedy: he was unaware of what was unfolding and was detained by the military. He was accused of trying to resist the Indonesian government. ${ }^{5}$ This experience was why, on 5 October 1998, Mr Jaja, after six months of Reformasi, came to Dewi Wardah's house, which was where the organisation known as Yayasan 12 September 1984 (12 September 1984 Foundation) was founded.

Mr Jaja and Mrs Yetty were the joint founding members of this organisation set up to help victims and their families. Through this organisation, they and most of the other victims prepared a case about the Tanjung Priok killings to take to a court. The name chosen, Yayasan 12 September 1984, expressed the collective identity of the victims. The intention of the organisation was to enable victims to articulate their hitherto suppressed/constrained memories of the event, to seek justice and to uncover the truth about the involvement of the Indonesian government.

This organisation, Yayasan 12 September 1984, coordinated the work of other organisations and groups, among which were Sontak (Solidaritas Nasional Korban Tanjung Priok [National Solidarity for Tanjung Priok Victims]) led by Syarifin Maloko, and Kompak (Komite Mahasiswa Pemuda Anti Kekerasan [Student Youth Committee for Non-violence) led by Yayan Hendrayana. The many organisations representing Tanjung Priok victims had same purpose; how to deal with the case of the Tanjung Priok killings. These organisations had engaged in many activities to sway Indonesian public opinion and attract sympathy; activities such as discussions, lessons and teachings from the Qur'an (pengajian akbar) and demonstrations.

The idea for setting up the organisation developed from a mass prayer gathering, titled Mimbar Kesaksian [testimony forum], which was attended by almost two thousand Muslims at the al-Husna mosque in Tanjung Priok on 12 September 1998. One of the speakers was Amien Rais, a religious leader from Muhammadiyah (a mass Islamic organisation). In his speech, Amien supported the victims' struggle to prosecute Indonesian authorities and for the victims to deal with their sufferings by asking for compensation, rehabilitation and reparation from the government. ${ }^{6}$ At this event, Mimbar Kesakian, memories were reinvigorated and compared and those who had been affected were consolidated as a group of like-minded victims. In other words, the group's collective memory of events helped reconstruct the past and give purpose to the future.

The organisations for victims helped members to recall and to understand their memories of the past traumas that they had been unable to express or communicate during the New Order period. ${ }^{7}$ The Reformasi administration that followed allowed the matter to be freed from official restraints, to be spoken about and perhaps for justice to be done.

4 At an interview on 8 November 2006, Mrs Yetty recalled that she was 18 years old in 1984 when her father left their house to join the mass prayer gathering not far away. Before departing, he kissed her mother and her and asked them to pray for his safety. They never saw him again. His death changed the family forever.

5 See Jaja A Raharja's testimony in Mereka bilang di sini tidak ada Tuhan, suara korban tragedi Priok. (Jakarta: Kontras and Gagas Media, 2004, p. 149).

6 Many religious leaders and prominent politicians came to the commemoration of the Tanjung Priok tragedy: Yuzril Ihza Mahendra of the Partai Bulan Bintang; Sayid Aqil Sirad, a religious leader of the Nahdatul Ulama, a mass Muslim organisation; Jalalludin Rahmat, a Muslim scholar; and Munir, an activist from KontraS. See 'Amien Rais dan Yuzril Ihza Hadir pada peringatan tragedi Priok'. Suara merdeka, 12 September 1998.

7 As Mary S Zurbuchen said of collective memory, 'how groups retain a sense of the past, and...how a sense of the past can inform a group's politics, religion, art, and social life in general'. See Zurbuchen (2005: 27). 
Those who had been affected one way or another by the Tanjung Priok events found that, although they were now free to articulate their account of what happened, their accounts were not consistent with the New Order's official version, which had become part of Indonesia's accepted or conventional social history. In short, their memory of events ran counter to the official version. Senior government and political party officials, who had instigated the massacre, were naturally not willing to countenance versions that did not support the accepted and official version.

These difficulties did not make the victims despair. Indeed, their solidarity was strengthened and made them determined to bring the perpetrators of the killings to a court. Many victims endured gunshot wounds, torture and three to five years in gaol. They were officially stigmatised by being labelled 'Islam Radikal' (radical Islam), or members of a fundamentalist Muslim group, Gerakan Pengacau Keamanan (GKN) or being members of the Communist Party of Indonesia (PKI).

\section{THE MECHANISM FOR SILENCING THE VICTIMS}

The prevailing history of the event was written and controlled by the New Order. The victims and their families were stigmatised and were unable to overcome this and to have their stories heard. How did the state or Orde Baru keep the victims silenced? Why were these methods so effective and for such a long time?

Until the Suharto regime fell in May 1998, the Priok killing had almost never been an Indonesian public issue: quite the reverse, discussing the Tanjung Priok killings privately, such as in private conversation between neighbours or friends could result in being arrested. Consequently, most of the Tanjung Priok people and, indeed, Jakarta people could not or would not refer to those events. Indeed, the normal democratic expectations about public events were not met; they were smothered by the Suharto administration. Stigmatising the victims and survivors was one way of ensuring that discussion was muted. The effect of the stigmatism remains still. ${ }^{8}$

A Mr Anshari and Mrs Yetty know what it is to be stigmatised. Before the tragedy, $\mathrm{Mr}$ Anshari often visited Tanjung Priok to give religious instruction and he helped mothers and children to read and to study the Qur'an. He engaged in these activities four to six times a week. Although he was a district religious leader (ustadz), some parents asked him to teach their children the Holy Qur'an. In addition, almost every Friday, some mosques asked him to give a religious address at Friday prayers. Mr Anshari had a wife and child and these activities gave him some extra income.

After he was released from gaol, he found that he was not often asked to give a religious address at a majelis taklim (mass prayer gathering). As well, the number of students who attended his study courses (reading the Qur'an) declined steadily. Rumours spread that he had been a member of a Qur'anic teaching group organised by Amir Biki, a person prominent in Tanjung Priok and who died on 12 September 1984. There were people who considered he (Mr Anshari) would encourage his students and members of his Qur'an teaching group to subvert government authority in his teaching. Here is his account.

Dulu sebelum saya kena peristiwa itu, saya bebas ngajar di mana-mana. Ngajar majelis taklim ibu-ibu dan remaja. Bahkan saya setiap jum'at ngisi khutbah jum'at bebas di mana aja. Semenjak peristiwa itu banyak mesjid-mesjid nolak saya. Banyak orang menganggap dan nuduh peristiwa Priok yang saya alami sejajar dengan PKI. Isi ceramah saya dianggap menghasut. Hingga sekarang omongan seperti itu masih ada, meski sampai sekarang sudah Reformasi. Pernah saya mengisi pengajian

8 According to Erving Goffman, 'stigma' is a term used to refer to an attribute that is deeply discrediting, but it should be seen that a language of relationships, not attributes, is really needed. An attribute that stigmatises one type of possessor can confirm the usualness of another, and therefore is neither creditable nor discreditable as a thing in itself. (Goffman, 1963: 3) 
remaja masih ada suara-suara masyarakat yang menyangka saya akan menghasut dan mengajarkan seperti Amir Biki. ${ }^{9}$

[Before the incident, I was free to teach everywhere such as teaching the Qur'an for mothers and children. Indeed, I was invited to address the faithful about Islam at Friday prayers. After Tanjung Priok, most official mosques ignored me. Some people thought of me as if I were a PKI member. What I had to say was thought to provoke people. Since Reformasi, there are still rumours dogging me that I am a teacher in the same style as Amir Biki.]

What Anshari said above shows how Indonesian people's attitudes and beliefs about Tanjung Priok are still coloured by the way those events and perceptions were manipulated and distorted by the Suharto regime. The regime has ended: the stigma remains. Indonesians could not think of Anshari as a person who had a social, cultural and family background very much like theirs: they identified him as other; one who opposed the government and tried to subvert national stability (mengganggu stabilitas nasional). Additionally, Anshari was not thought to be a religious leader who frequently spoke on Islam. Indeed, public opinion redefined Anshari; he was given the attributes that were that were understood to belong to those who resisted authority in September 1984.

After Mrs Yetty's father was killed, she replaced him as breadwinner to support her mother and her two younger siblings. Although she had a senior-high-school certificate, she found that companies to which she applied for work, refused to employ her. 'In each institution it was as if the firm had been given a list of the victims and their families. So if the victims or their family members were on the list, they would not be accepted by the organisation to which they had applied', she said. A rumour spread that the children of Tanjung Priok victims were members of the PKI (Communist Party of Indonesia) and GPK participants. From the Orde Baru's perspective, members of these organisations were enemies of the state. Therefore, some institutions would not accept nor be involved in business with the victims or their families.

In fact, there is no connection between the victims of Tanjung Priok and the upheavals of 1965 and 1966 nor any connection with the PKI. Tanjung Priok victims and their families were members of a Muslim community and opposed to the PKI. Besides, some victims were prominent figures known to be very much opposed to the PKI. Indeed, the Orde Baru regime's propaganda asserted that the PKI was atheistic, which is in direct contradiction to Muslim theology. The term 'PKI' was used by Suharto and the Orde Baru to dominate and control all movements and activities that the regime considered subversive. According to Ariel Heryanto (2007), in Indonesia, any term used to refer to communism was 'a floating empty signifier' that carried connotations of the threat of communism. In other words, it had become a self-referential term and, in this sense, any implied communist threat appears to become 'more than real' or 'hyperreal' in Baudrillard's sense (Budiawan, 2005: 4).

Mr Anshari and Mrs. Yetty's experiences were similar to stories related by other victims' families. They were haunted and influenced by their memories. But they had to continue their lives carrying the burden of being stigmatised as people who had opposed the government. They were relegated economically to the periphery, to the informal sectors, where they worked as fruit sellers, small shopkeepers and the like.

Strigmatism by the Suharto regime was only too effective. By using many terms that had negative connotation for historical reasons, such as komunis and GKN, by reinforcing the negative connotations and attaching those terms as defining characteristics of a person or group meant that those stigmatised had their identity replaced in effect and it was this identity that was judged and attracted discrimination. A person suffering from the imposed stigma found that their relations within their ethnic group, with their co-religionists and with their community were dominated by their re-

9 Interview on 9 November with Mr Anshari, a Tanjung Priok victim. 
identification, which constricted their lives (Hardiman, 2005: 9-14). Under these depersonalising restrictions, victims were not able to articulate their stories and memories nor to rise above their reduced circumstances but there were some strategies that they used to keep their stories in focus in their memory for the time when their plight could be redressed.

\section{RESTORING THE VOICES OF THE SILENCED BY SITES OF MEMORY}

For the victim, a memory is not only the recorded past but also a lever for uncovering truth of the past. If the victims' individual memories can be deconstructed through the experience of transmitting and sharing those memories, then a collective memory can be constructed to illuminate the past, understand the present and to imagine and give hope for the future. With no collective memory, that is, no sharing of recollections of events, no insight nor understanding of the big picture, no knowledge of others' experiences, the victims cannot with confidence organise, negotiate, cooperate and fight for change (Climo and Cattle, 2002). Thus, memory, whether individual or collective, is constructed and reconstructed by the dialectics or remembering and forgetting, shaped by semantic and interpretive frames, and subject to panoply of distortion. Furthermore, the articulation of memories as constituents of collective memory will produce a resource for undermining or negating the dominant discourse that was created by the authoritarian regime.

A way to know how they articulate their memory is to see how it is stored. The historian Pierre Nora's explication of the 'sites of memory' is helpful in understanding the social nature of remembrance. For Nora, borrowing the concept of collective memory from the French sociologist Maurice Halbwachs, human beings can remember their history but cannot freely choose the circumstances and conditions of their remembering. In other words, social environments influence and shape an individual's capacity to remember and to recall. On a collective level, memories are constructed within present frames of reference such that sites of memory are defined as places and items that possess the capability to store and to trigger acts of remembering (Schreiner, 2005: 266).

The victims have used three ways to create sites of memory: rites, a monument and memoirs. These are not used as a means of reviving the hurt and bitterness, rather they are to be a release by putting their group's experiences in the public domain to show that they are not alone. These activities might not enable them to recover fully from their trauma but, at least, it could be some compensation for their burden.

\section{RITES}

The Tanjung Priok victims and their families created two rites, one before and one after Reformasi. First, tahlilan, which can be a prayer meeting in praise of God or for a family member who has died. After isya, evening prayers, most Kampung Koja people in Tanjung Priok attended Qur'an teaching. Previously, tahlilan was a rite involving prayers for victims who had died. ${ }^{10}$ Tahlilan performed after prayers was particularly important on Friday evenings because the Prophet Muhammad had ordered that it was good time for a family to pray for the dead. This tahlilan rite began after the Tanjung Priok incident. The second rite was the Priok Commemoration. There were many ways of commemorating, such as big demonstrations with theatrical re-enactments of demonstrators being shot and followed by prayers for those victims who died. This commemoration rite started after Reformasi. ${ }^{11}$ These two rites gathered force over time and helped to strengthen the victim's group

10 Interview on 6 November 2006 with Yusron, a Tanjung Priok victim.

11 See 'Amien Rais dan Yuzril Ihza Mahendra hadir pada peringatan Tragedi Priok', Suara Merdeka, 13 September 1998; 'Ribuan massa peringati Tanjung Priok', Kompas, 13 September 1998; 'Peringatan 16 tahun tragedi Priok, empat patung jenderal dibakar, Kompas, 13 September 2000; '16 tahun tragedi Priok diperingati dijakarta', Media Indonesia, 13 September 2000; 'Semoga kebenaran mengemuka di pengadilan' Suara pembaharuan, 13 September 
memory: each rite helped to reinforce the other. The aim of these activities was to get Indonesian public sympathy and understanding by using changed conditions after Reformasi as a catalyst in efforts to counter the injustices of the Suharto regime.

\section{MONUMENT}

The utility of a grand monument might, on first thought, be to remind us of the glories of the past but monuments can also distract us from the realities of the events being commemorated so that we are not caused to question the historic circumstances (Santikarma, 2005: 319). The Lubang Buaya museum and the Pancasila Sakti monument are both sites of memories built by the Suharto regime to distort or falsify the Indonesian social memory by commemorating the PKI as the organisation responsible for the infamous murders of seven generals on 1 October 1965. In fact, what occurred was a mass extermination; without legal justification, with no administrative procedure and without going before a court, an extermination of members of the PKI, sympathisers of the party's activities, and other people in Java and in Bali in 1965-1966 who could be designated enemies of the state. ${ }^{12}$ A monument, in other words, is a way to represent or symbolise the powers in a society: monuments of all kinds, buildings, sculpture and more, give substance to national myths or ideals and in doing so help to control or to give an impression of the past. ${ }^{13}$

The description above denotes an intolerant, brutal and authoritarian regime: how did victims and their families establish sites of their memory? They could not create a public monument in the form of a statue or an arch; they must use an existing site and invest it with the meaning and significance that they wanted. For the Tanjung Priok and Jakarta people, the small mosque of Assa'adah became the monument that stored the collective memory of the events of Tanjung Priok because it was at the Assa'adah mosque that the tragedy occurred. Perhaps the office of 0502 District Military Command (Kodim 0502) in Sunter district, North Jakarta, or the Rumah Tahanan Militer (Military Detention House) in Cimanggis could be considered the real monuments. These places were where victims were tortured and their humanity violated by the military and certainly were sites of memory but not ones that could give comfort to the survivors. One monument, or site of memory, is the grave of Amir Biki, which is behind his family's house. Amir Biki's grave and the Assa'adah mosque are the edifices, small as they are, that have kept memories of the tragedy alive.

The mosque is a prime site of memory because Amir Biki died there on 12 September 1984: he was the only person with religious status to die on that occasion. Indeed, his death was considered martyrdom by most victims and their families. Generally, he personified the site of collective memory for Indonesians. In fieldwork interviews, I found that the name that came up most often in discussions about Tanjung Priok was that of Amir Biki-Tanjung Priok and Amir Biki are inseparable in the public's mind. Amir Biki's grave has pride of place for his family as that of a martyr for the cause. Mr Bodi, Amir Biki's elder brother, has affirmed to Amir Biki's children and

2001; 'Diperingati peristiwa Tanjung Priok' , Kompas, 13 September 2003; and 'Korban Tanjung Priok Kecewa', Kompas, 13 September 2006.

12 Even now, no one can be sure how many people were killed in the upheavals of 1965-1966. There were about 1.5 million Indonesians accused of being members of the PKI and gaoled. In 1981, this number was officially confirmed, that is, that there had been 1.5 million people gaoled as a result of the purge; later figures put it at 1.7 million. For more information, see Roosa et al. (2004: 9).

13 For a comprehensive account of how the Suharto regime shaped Indonesian social memory through books, amendments to history and museums, see McGregor (2007). 
grandchildren that 'Here [Amir Biki's grave] is where the warrior that was your grandfather now lies, and why I want all of you know what he stood for and to understand him'. ${ }^{14}$

\section{MEMOIRS}

A man of letters once said that if we give someone a book, it is not only giving him paper and ink but also to give him a new life. In other words, an author through his narrative writing can give readers a transformative experience. For victims of violence, writing an account of what happened is not only a transformative experience for them but also a first-hand account by a witness. By writing about what they witnessed, victims are able to break their silence and to garner public sympathy. As well, writing memoirs and books is to tell the story of the Tanjung Priok killings from the victims' perspective. Until these stories were published, the narration of the Tanjung Priok story was dominated by the Suharto regime. Published accounts of the atrocity, books and memoirs, all add to the knowledge of the event and help us to judge the victims and the perpetrators. As well, these stories are challenging the Orde Baru's version and control of the history and that had permitted no contrary opinions.

Memoirs that have been published are:

Tanjung Priok berdarah: tanggung jawab siapa. (Pusat Studi dan Pengembangan Informasi dan Gema Insani Press, 1998).

Dari mimbar ke penjara: suara nurani pencarian keadilan dan kebebasan. (AM Fatwa, 1999).

Pembantaian Tanjung Priok rabu 12 September 1984, mengenang 15 tahun kasus Priok, 1984-1999. (Yudi Pramuko, 1999).

Pancasila, de-Islamisasi dan politik provokasi. (Moch. Syarifin Maloko, (2001).

Mereka bilang disini tidak ada Tuhan, suara korban peristiwa Priok. (Tim Kontras, 2004).

Menuju kedamaian nan indah, merajut pesan sejarah perjuangan Alm. H. Mohammad Amir Biki. (Abd. Rusly Biki and R Yasin, 2005).

\section{CONCLUSION}

This paper has explored how the memories of the victims and their families have been articulated after the Suharto regime. Now that the Suharto regime is no more, the Tanjung Priok victims may articulate their memories that have haunted them since 1984. The traumas of gaol and torture, the regime's stigmatising, the marginalisation of their lives can now be redressed, normal social relations be established and the victims be readmitted to the mainstream. Repressed as they had been, the victims were able to keep their memories alive by creating sites of memory in the way of rites, monuments and memoirs.

The period after the fall of Suharto in May 1998, well known as Reformasi, allowed victims the freedom to articulate their memories in ways described and to ask questions about the government's responsibility for past human rights abuses that had occurred under Suharto. Reformasi allowed public discussion, open communication and for victims to have their injustices publicised and redressed. This change in the political and social climate resulted in the formation of organisations to help Tanjung Priok victims; organisations such as Sontak (Solidaritas Nasional Korban Tanjung Priok [National Solidarity for Tanjung Priok Victims]) and Kompak (Komite Mahasiswa Pemuda Anti Kekerasan [Youth Student Committee for Non-violence).

14 Interview on 4 November 2006 with H Bodi, elder brother of Amir Biki. 


\section{BIBLIOGRAPHY}

Books and articles

Amstutz, MR. (2005). The healing of nations: the promise and limits of political forgiveness. Lanham: Rowman and Littlefield.

Budiawan. (2005). 'Komunis(me) tidak pernah mati?' Bulletin nadheer, published by the postgraduate of Religious and Cultural Studies, Sanata Dharma University, 4(4): 4.

Climo, Jacob J and Maria G Cattell (eds). Social memory and history: anthropological perspectives. Walnut Creek: AltaMira Press, 2002.

Goffman, Erving. (1963). Stigma, notes on the management of spoiled identity, New York: Touchstone.

Hardiman, F Budi. (2005). Memahami negativitas, diskursus tentang massa teror, dan trauma. Jakarta: Kompas.

Heryanto, Ariel. (2007). State terrorism and political identity in Indonesia: fatally belonging. London and New York: Routledge.

McGregor, Katharine E. (2007). History in uniform: military ideology and the construction of Indonesia's past. Honolulu: University of Hawaii Press.

Roosa, John, Ayu Ratih and Hilmar Farid (eds). (2004). 'Sejarah lisan dan ingatan sosial'. Tahun yang tak pernah berakhir: memahami pengalaman korban 65, Jakarta: Elsam, Tim Relawan with Kemanusiaan, and Institut Sejarah Sosial Indonesia.

Santikarma, Degung. (2005). 'The politics of representing violence in Bali'. In Mary S Zurbuchen (ed.). Beginning to remember, the past in the Indonesian present. Seattle: University of Washington Press, p. 319.

Schreiner, Klaus H. (2005). 'Lubang buaya: histories of trauma and sites of memory'. In Mary S Zurbuchen (ed.). Beginning to remember, the past in the Indonesian present, Seattle: University of Washington Press.

Sunardi. (2006). 'Lacanian subject'. Unpulished paper in the Postgraduate School of Religious and Culture Studies, Sanata Dharma University, Yogyakarta.

Zurbuchen, Mary S. (ed.). (2005). Beginning to remember, the past in the Indonesian present. Seattle: University of Washington Press.

Newspapers

'Amien Rais dan Yuzril Ihza Hadir pada peringatan Tragedi Priok', Suara merdeka, 12 September 1998.

'Amien Rais dan Yuzril Ihza Mahendra hadir pada peringatan tragedi Priok', Suara merdeka, 13 September 1998.

'Ribuan massa peringati Tanjung Priok', Kompas, 13 September 1998.

'16 tahun Tragedi Priok diperingati di Jakarta', Media Indonesia, 13 September 2000.

'Peringatan 16 tahun tragedi Priok, empat patung jenderal dibakar, Kompas, 13 September 2000.

'Semoga kebenaran mengemuka di pengadilan', Suara pembaharuan, 13 September 2001.

'Korban Tanjung Priok kecewa', Kompas, 13 September 2006. 


\section{Interviews}

Interview on 4 November 2006 with H Bodi, elder brother of Amir Biki, a prominent Islamic teacher who was killed in the Tanjung Priok tragedy.

Interview on 8 November 2006 with Mrs Yetty, a member of a victim's family.

Interview on 9 November 2006 with Mr Anshari, a Tanjung Priok victim.

Interview on 6 November 2006 with Yusron, a Tanjung Priok victim.

Jaja A Raharja's testimony (2004). In Mereka bilang di sini tidak ada Tuhan, suara korban Tragedi Priok. Jakarta: Kontras and Gagas Media. 